DOI https://doi.org/10.30525/978-9934-571-83-1-14

\title{
GENDER BUDGETING AS A MEANS \\ OF ENSURING THE GENDER EQUALITY PRINCIPLE
}

\author{
Nalyvaiko L. R., Hrytsai I. O.
}

\section{INTRODUCTION}

Social development in Ukraine is oriented towards democracy and harmonious development of the individual. The effectiveness and dynamics of the economy of each country depends more on how many resources and how the state invests in human capital. The consideration of the gender factor is a key aspect of the effectiveness of this process, since not only the general needs of a person are considered, but also the differentiation of needs from the point of view of the biological, social differences of each individual. Many important phenomena, both economic and social, such as economic development, unemployment, poverty, are not gender-neutral and affect men and women differently. The inclusion of individual elements of a gender perspective in public policy will allow you see, analyze and compare to what extent and why economic, political, social and other factors affect women and men in different ways.

New benchmarks for Ukraine's development, key goals and objectives for harmonious partnership in society, the implementation of gender approaches as a component of strengthening democracy encourage significant changes in the strategy of achieving gender equality under the influence of gender-oriented budgeting. Among the many gender policies, gender budgeting is crucial. Integrating a gender component into the budget process and re-structuring incomes and expenditures in such a way that the needs of women and men are adequately represented in budget articles are the main directions of realization of this issue.

The ultimate goal of gender-oriented budgeting in Ukraine should be to improve the budget process through a gender-oriented approach that will help reform the public finance management system in Ukraine. The content of gender-oriented budgeting is the adoption and implementation of budgets and programs that take into account the specific needs of men and women. Budgeting with gender-specific features makes it transparent, money is spent efficiently, all social and gender groups receive services.

In Ukraine, the problems of increasing the efficiency of the functioning of the budgets, including the ones by means of introducing gender budgeting, are devoted to the work of specialists of various fields of science: D. Amirkhanov, O. Anastasieva, J. Belets, B. Blyzniuk, O. Bozhko, M. Bosnich, I. Vorchakova, 
S. Garashchenko, A. Gerasymenko, O. Golynska, N. Goncharik, S. Danylenko, L. Denha, I. Zapatrina, A. Yermoshenko, T. Ivanina, S. Kovalenko, N. Kornienko, O. Kravchenko, G. Levkivska, L. Lobanova, L. Lysiak, O. Lisovyi, I. Miniailo, M. Movchan, A. Nikoliuk, Yu. Ostrishchenko, S. Pasichnyi, N. Petrenko, O. Punda, N. Radchuk, O. Romaniuk, A. Serednytska, I. Sovsun, M. Sokolyk, V. Stetsenko, I. Turetska, I. Uskova, T. Fediushkina, O. Tsiupa, O. Cherniuk, I. Chugunova, K. Shmitts and etc.

\section{Domestic and foreign experience of implementing gender-oriented budgeting: a retrospective and modern times}

Today, gender-oriented budgeting in Ukraine is at the stage of studying and research at local levels and at the stage of its formation and introduction into the national system. But, despite the developed legal framework on gender equality issues, the main problems are the insufficient level of implementation of the provisions of the legislation. The legal basis for implementation of measures to realise gender budgeting is the Constitution of Ukraine, the Law of Ukraine "On Ensuring Equal Rights and Opportunities for Women and Men", the Budget Code of Ukraine, the Order of the Cabinet of Ministers of Ukraine "On Approving the Strategy for Reforming the Public Finances Management System for 2017-2020", as well as international conventions ratified by Ukraine.

The current legislation creates a broad legal basis for the integration of social aspects in the process of budget formation in Ukraine. But, the lack of a single strategic document that would determine the need for gender budgeting and consolidate the methodological basis for its implementation impedes the process of introducing such budgeting. Solving the problem of existence of inequalities between women and men and allocating state resources with a gender perspective is possible by introducing elements of gender budgeting into the budget and gender analysis at the legislative level.

The concept of gender-oriented budgeting was conceived as a flexible mechanism for developing targeted strategies to ensure a fair distribution of resources for the benefit of different social groups, enabling researchers and practitioners to broaden its context by ensuring its functioning as an effective tool for social inclusion and gender equality.

At the normative level, the concept of gender-oriented budget and genderoriented budgeting were proposed in the Platform for Action adopted at the Beijing Conference in 1995. The strategy of the integrated approach to the issue of gender equality was adopted by most countries as the most promising and effective for the promotion of gender equality. The Platform for Action notes that governments 
should make every effort to systematically study how the public sector benefits women and to adjust budgets to ensure equal access to them ${ }^{1}$.

In the national scientific literature, the concept of gender budgeting has been used since the early 2000s and many scholars and researchers have tried to define this term, but so far, there is no definition in the dictionaries and encyclopedias.

The content of the concept of gender budget is presented in the analytical report of the International Centre for Policy Studies "Potential of Ukraine and its realization" within the framework of the project "Capacity to analyze socioeconomic outcomes and potential". The project leader O. Romaniuk proposes the following definition of the gender budget: a budget that takes into account the planning of the country's resources, with regard to budget revenues, which are formed at the expense of women and men, and budget expenditures allocated to women and men, and is aimed at the analysis of any kind of state expenditures or methods of attracting public funds taking into consideration the gender component, defining the consequences and impacts of implementation of budget decisions on persons of the female and male $\operatorname{sex}^{2}$. S. Garaschenko, in her turn, proposed the following definition of the gender budget: a balanced consideration of the interests and needs of each of the sexes, as special social groups, during the planning and implementation of financial expenditures for the provision of public services (in the field of education, health care, etc.) ${ }^{3}$.

In the process of implementation of the initial stages of the project "Gender budgeting in Ukraine", the author's definition of content of the concept of gender- oriented budgeting is presented in the study: it is the application of a comprehensive gender approach in fiscal policy and budget process at the state and local levels, which includes the distribution of budget funds on a gender basis, as well as increasing transparency and accountability. Gender-oriented budgeting is a way of budgeting at the centre of which there are specific people, women and men from different social and demographic groups ${ }^{4}$.

Consequently, gender budgeting, gender-oriented budget, gender-sensitive budget, gender responsive budget - all these terms are synonymous. This type of

\footnotetext{
${ }^{1}$ Пекінська декларація (укр./poc.), прийнята на четвертій Всесвітній конференції зі становища жінок 15.09.1995 p. Бібліотечка голови профспілкового комітету. 2005. № 5. URL: http://zakon3.rada.gov.ua/ laws/show/en/995_507 (дата звернення: 25.01.2018).

${ }^{2}$ Грицай I.O. Теоретико-правові засади гендерно-орієнтованого бюджетування: зарубіжний досвід та вітчизняна практика. Науковий вісник публічного та приватного права. 2017. № 6. С. 3.

Романюк О. Потенціал України та його реалізація. Аналітичний звіт Міжнародного центру перспективних досліджень. Київ, 2009. 69 с.

${ }^{3}$ Гаращенко С.В. Гендерне бюджетування як складник політичних механізмів сприяння забезпеченню рівності жінок та чоловіків. Наукові записки. Т. 95. С. 47-51. URL: http://ekmair.ukma.edu.ua/bitstream/ handle/123456789/3999/Harashchenko_Henderne.pdf.

${ }^{4}$ Гендерний бюджетний аналіз програм, які фінансуються з державного та місцевих бюджетів. Київ, 2016. $89 \mathrm{c}$.
} 
budget should ensure balanced consideration of the interests and needs of women and men. At the same time gender budgets are not separate for women and men, it is a means of integrating gender issues into government policies and budgets of different offices, departments and institutions. The gender budget is an analysis of income and expenditure of the state; a set of different tools and methods, united by the general purpose - to make the gender approach one of the obligatory principles in politics and economy.

Taking into account the provisions of the existing definitions of the gender budget, we propose to understand it as a balanced consideration of the needs and interests of women and men through the introduction of methods aimed at integrating the gender component into the budget process at all levels of the budget system.

It is necessary to distinguish between the terms "gender budget" and "gender budgeting". Gender budgeting is one of the tools for achieving gender equality, the mechanism of which covers the political, economic and social spheres of ensuring equality between women and men $^{5}$. Gender-oriented budgeting should be considered as an influential element of management activity related to the development of budgets of different levels, which provides important information to specialists who decide on the distribution of budget funds. Broadly, gender-oriented budgeting is an instrument that provides an opportunity to implement a state policy of guaranteeing equal rights and opportunities for women and men at the expense of budget funds ${ }^{6}$.

The potential of gender-oriented budgeting is quite large, and its implementation has many advantages. The experience of many countries suggests that gender-oriented budgeting contributes to improving the efficiency of public spending, the quality of programs and services for the population, and the rates of economic development of the territories. Other benefits of genderoriented budgeting include the ability to increase the effectiveness of policy implementation and to ensure greater accountability of government agencies; to improve laws and policies in order to overcome existing gender issues; to reduce gender inequality and give impetus to the development of gender-sensitive policies; to monitor the achievement of political goals and statements regarding gender equality; to encourage the achievement of the goals of gender equality and human development; to increase transparency, accountability and public participation in the planning and implementation of budgets.

Gender-oriented budgeting is also a tool for improving international aid effectiveness. The Monitoring Report of the International Monetary Fund and the

\footnotetext{
${ }^{5}$ Остріщенко Ю.В., Корнієнко Н.М. Гендерне бюджетування на місцевому рівні як інструмент підвищення ефективності використання бюджетних коштів. Механізм регулювання економіки. 2015. С. 19-27.

${ }^{6}$ Іваніна Т., Жукова О., Євченко С. Гендерно-орієнтоване бюджетування в Україні: теорія і практика : методичний посібник. Київ : Клименко, 2016. 92 с.
} 
World Bank (2007) proves that gender equality has significant economic implications and contributes to the achievement of development goals. It also emphasizes that women's empowerment plays a central role in this process and requires the transformation of the goal of achieving gender equality into a universally accepted goal requiring technical qualification and funding ${ }^{7}$. The IMF's report "Women, Labor, and Economics: Macroeconomic Benefits of Gender Equality", published in 2013, highlights the importance of gender issues for macroeconomics, assessing GDP per capita losses as a result of gender differentiation in the labour market. It is anticipated that the IMF's further work will take into account the gender implications of implementing programs and activities.

For the first time, the principle of gender-oriented budgeting was applied in the form of a "female budget" in Australia in 1984, which was seen primarily as an anti-crisis instrument. The gender distribution of the budget envisaged a restructuring of incomes and expenditures, not aimed at increasing the funds, but at revising existing resources. And since then, it has been implemented in a number of countries as one of the strategies for achieving gender equality ${ }^{8}$. In many cases, the initiative was constrained by the lack of statistical data or cooperation from the government at different levels. However, many countries have begun implementing gender budgets as pilot projects, and in some countries such projects have made significant progress (for example, in Austria, Belgium, Great Britain, Spain).

Thus, in Austria the gender component in budgeting is being implemented within the framework of a large-scale budget reform at the federal level. These reforms have covered all processes related to management, the entire budget cycle, as well as the annual budget, its planning, implementation and control over the implementation. Each year, together with the draft budget, a gender budgeting project is submitted to the municipality, and a report on the gender budget audit is prepared as an annex to the annual audit report. In the context of fiscal management and control, gender budgeting is used as a tool to increase the effectiveness of policies through the accounting of socio-economic needs and needs of women and men ${ }^{9}$. In Sweden, gender budgeting, the projects of which began in 2003, came out of the project stage and became part of the work of the government that implements the gender budgeting process in all policy areas ${ }^{10}$.

\footnotetext{
${ }^{7}$ Global Monitoring Report 2007: Confronting the Challenges of Gender Equality and Fragile States. World Bank and International Monetary Fund. URL: https://www.imf.org/external/pubs/ft/GMR/2007/eng/gmr.pdf.

${ }^{8}$ Budlender D., Hewitt G. Gender Budgets Make More Cents Country Studies and Good Practice. Commonwealth Secretariat. Marlborough House, Pall Mall, London. 2002. P. 7 -8.

9 Геппл М., Фестл Э. Гендерное бюджетирование в Австрии. Первый опыт. Польша. 2015.11 с. URL: http://www.pempal.org/sites/pempal/files/event/attachments/d1-pm-s2.b-monica-geppl-austria_rus.pdf.

10 Матеріали до семінарів із впровадження гендерних підходів у політику. Програма підтримки партнерства жінок та чоловіків у політиці «Ольга». Київ : б. в., 2002. 49 с.
} 
Sweden, having conducted in-depth studies of gender issues, such as the financial situation of older women and men and the economic cost of fulfilling parental responsibilities, significantly expanded the information on existing gender disparities and included specific annexes to the budget.

In 2007, laws were passed in Belgium that detail the methodology of gender budgeting. This methodology should be regulated by the Federal Service for State Control of the Budget, an authority which has full responsibility for all issues related to the budget. Scotland has introduced a report on the impact on equality, which highlights the impact of political reforms and public expenditures and revenues on gender equality. In France, an annual report on the impact of the budget on gender equality is prepared in the framework of budgetary materials ${ }^{11}$. In the European Union, the official recognition of the gender budgeting strategy was received in 2001 during the High Level Conference "Strengthening Economic and Financial Management through Gender Budgeting". At this conference, it was stated that 2015 would become targeted for the adoption of the gender budgeting strategy by all EU Member States ${ }^{12}$.

Henceforth, gender budgeting has become a topical issue of political discourse and political action in many countries, international organizations and intergovernmental organizations, in particular the Council of Europe, the European Parliament and the Council of Ministers of the Nordic countries ${ }^{13}$. In 2015, the Budget Committee of the European Parliament adopted an amendment on the introduction of gender-oriented budgeting as part of the discussion of the draft budget for 2016. In particular, these allocations should be aimed at designing and applying the methodology of gender-oriented budgeting to the EU budget. This decision means that the annual budgetary procedures will include a gender perspective, and it calls for the full implementation of gender budgeting.

In Ukraine, the practice of gender budget initiatives was first implemented in 2003 by the Kharkiv Women's Fund, which first analyzed the city budget for 1998-2001, as a result of which the subprogram "Development and Support of Women's Entrepreneurship" was adopted as part of the "Economic program of development of the city of Kharkiv for 2003-2005 years". Subsequently gender budgeting was conducted in Kherson, Poltava, Cherkasy and other areas.

Since 2006, the issue of gender budgeting in Ukraine has become the focus of various programs and projects, in particular, the joint program of the European Commission, UN Women and the International Training Centre of the ILO

\footnotetext{
${ }^{11}$ Country Specific Information. European institute for gender equality. URL: http://eige.europa.eu/gendermainstreaming/countries.

${ }_{12}$ Strengthening economic and financial governance through gender responsive budgeting. Conference report. Brussels. 2001. 106 p. URL: https://www.internationalbudget.org/wp-content/uploads/ gender_report_conf_oct01.pdf.

${ }^{13}$ Малиняк Б., Іваніна Т., Гаращенко С. Гендерне бюджетування в Україні. Київ : б. в., 2010. 34 с.
} 
(ITCILO) "Collaboration on Gender Equality for Development and Peace", the Swedish International Development Cooperation Agency (SIDA) and the United Nations Development Program (UNDP), the Equal Opportunities and Women's Rights Program in Ukraine, the project of the Swedish International Development Cooperation Agency SIDA "Strategy for the Achievement of Gender Equality in Ukraine", a joint EU project, etc.

Since 2011, the process of implementation of the gender perspective in the budget process of Ukraine has begun. To this end, a pilot project "Genderoriented budgeting at the local level" was implemented during the years 20112012 in Ivano-Frankivsk and Luhansk regions with the support of the Swedish International Development Cooperation Agency (SIDA). Within the framework of the project, a number of budget programs, namely "Youth of Prykarpattia", "Education Development of Ivano-Frankivsk Region" and Regional Program of Physical Culture and Sports Development of Luhansk Region, have been analyzed as for considering gender aspects in them. The project has greatly contributed to the development of national experience and possible tools in the process of budgeting and implementation on a gender-oriented approach. The purpose of the project is to study the essence and principles of gender budgeting; to carry out gender expertise of the budget in order to take into account the special needs of different gender groups; to approve possible approaches to introducing a gender perspective into the budget.

From 2011 to 2015, the UN Women in Ukraine implemented the program "Increasing Liability for the Financing of Gender Equality". The program seeks to address financing and accountability issues in order to meet commitments on gender equality. The overall objective of the program is to increase the volume and improve the efficiency of donor assistance and national resources to meet national commitments on gender equality and empowerment of women ${ }^{14}$.

In 2014, the implementation of the project "Gender Budgeting in Ukraine" was launched in order to ensure further testing of the gender component in the budget process and increase the cost-effectiveness of budget expenditures through the use of gender-oriented budgeting. This project is being implemented with the help of international consultancy companies Indevelop, CPM, HIPAC and financial support of the Swedish International Development Cooperation Agency SIDA. The beneficiary of the project "Gender Budgeting in Ukraine" is the Ministry of Finance of Ukraine, which coordinates the cooperation of sectoral ministries (Ministry of Education and Science, Ministry of Health, Ministry of Social Policy and Ministry of Youth and Sports) and regions on this issue, and heads the process of gender budgeting. The planned project lifetime is 5 years (November 2013 - December 2018). It is also planned to establish

\footnotetext{
${ }^{14}$ OОН Жінки. ЮНЕЙДС. URL: https://unaids.org.ua/ua/about-unaids/diyalnist-v-ukrajini/oon-zhinky.
} 
cooperation with the following direct partners: a group of selected sectoral ministries; relevant committees of the Verkhovna Rada; all regional administrations; selected public organizations; selected educational institutions.

The project is based on best international practice and includes benchmarking of gender budgeting at the level of pilot sectoral ministries and regions with a view to further deepening the gendered approach to the budget process at all stages of the budget system. Implementation of the project involves the use of gender-oriented budgeting in the budget process at the state and regional levels and ensuring the preparation of the first gender-oriented budget in Ukraine for 2019.

The "Gender Budgeting in Ukraine" project was initiated by the Ministry of Finance of Ukraine, which demonstrates the understanding of the importance of gender-oriented budgeting for the ongoing reform of public finances. In addition, the integration of gender-oriented budgeting into the public finance management system in Ukraine will contribute to increasing the efficiency of using budget funds, improving the model of state strategic planning and balanced development of society by securing interests and taking into account the needs of women and men, including the ones from different social groups.

\section{Problems and perspectives for further implementation of gender budgeting in Ukraine as a means of ensuring the principle of gender equality}

The activities related to gender budgeting include a range of different measures, including research, public awareness, advocacy, monitoring, training, and policy analysis and policy development. In the process of working on a variety of gender initiatives, different actors can be involved. The nature of these activities depends to some extent on who implements them. In some cases, all attention is paid to the budget process and to who it participates at different stages, in others - to measures that are more appropriate at one or another stage of gender-oriented budgeting, and issues of participation go back to the background. The composition of the participants involved in the implementation of gender budget initiatives will depend on who initiates the project of genderoriented budgeting and what tasks they put on themselves. From the public side participants of this process can be expert community, communities, public organizations, mass media and others. Countries where there is a political will to enforce equality, and where gender budget promoters have supporters in the government or parliament, have a more successful public impact on state budget allocations in favour of gender equality.

In terms of methodology, a gender-oriented budget is a financial and economic analysis of the income and expenditure of a state where gender analysis and financial literacy are closely intertwined with knowledge in the 
preparation and management of programs and projects. There is no single approach or model of gender-oriented budgeting, since different countries are guided by different actors, different strategies, tasks and deal with different political situations, cultural traditions, etc. ${ }^{15}$. The methodological development of gender budgeting analysis of the United Nations Development Program and the Secretariat of the British Commonwealth, developed by D. Badlender, was the most recognized and popular in the world. It offers a methodology for the five stages of the gender budget analysis and budget initiatives: 1) a description of the current situation; 2) assessment of existing policies, programmes and projects in terms of their gender sensitivity; 3) assessment of conformity of financial (budget) and other resources; 4) monitoring; 5) analysis of the relationship between the implemented policy and implemented expenditures ${ }^{16}$.

Other well-known methods and approaches include the following:

"7 steps in gender budgeting" is a methodology proposed as a guide for the implementation of gender budgeting in Austria. This methodology includes 4 phases and 7 steps of gender budget analysis: Phase 1 - Training; assessment of prerequisites and outcomes in the field; identification of existing problems in the field; Phase 2 - Analysis; Phase 3 - Implementation. Work at this stage involves the development of criteria and indicators for the achievement of the goals of gender equality and the development and implementation of gender budgeting measures (Steps 5 and 6); Phase $4-$ Control $^{17}$. The approaches of Austrian researchers to gender budgeting were used by the finance departments of the Ivano-Frankivsk, Lugansk regional state administrations and project experts in the process of developing a methodology for carrying out gender expertise of budget expenditures ${ }^{18}$.

"Method 4R" is an instrument developed in Sweden in 1990 by G. Ostrem and the Union of Municipalities of Sweden within the framework of the Jom Stod project and improved in the 2000s. The 3R method was developed by the

\footnotetext{
15 Іваніна Т., Жукова О., Євченко С. Гендерно-орієнтоване бюджетування в Україні: теорія і практика : методичний посібник. Київ : Клименко, 2016. С. 64.

${ }^{16}$ Budlender D., Elson D. Gender Budgets Make Cents: Understanding Gender Responsive Budgets. Gender Affairs Department. 2002, 180 p. URL: https://www.internationalbudget.org/wp-content/uploads/GenderBudgets-Make-Cents-Understanding-Gender-Responsive-Budgets.pdf.

Written comments of the European Roma Rights Centre and the International Charitable Organization Roma Women Fund "Chiricli" Concerning the Republic of Ukraine for consideration by the Committee on the Elimination of All Forms of Discrimination against Women at its 45th session. URL: http://chirikli.com.ua/index.php/ua/component/k2/item/82-written-comments-by-the-european-roma-rightscentre-and-the-international-charitable-organization-roma-women-fund-chiricli.

17 Austrian Experience Performance Budgeting. Friederike Schwarzendorfer. Austrian Federal Ministry of Finance. 57 p. URL: https://slideplayer.com/slide/12030238/.

Frey R., Köhnen M. Guidance Gender Budgeting in Public Administration. Vienna, 2012. 43 p.

18 Остріщенко Ю.В., Корнієнко Н.М. Гендерне бюджетування на місцевому рівні як інструмент підвищення ефективності використання бюджетних коштів. Механізм регулювання економіки. 2015. C. 19-27.
} 
local government in Sweden to analyze the impact of programs and decisions on the population groups. This method involves the collection and processing of quantitative and evaluative information: $1 \mathrm{R}$ - Representation: representation of men and women (quantitative analysis) in different structures and at different levels of the administrative apparatus; 2R - Resources: analysis of the distribution of financial resources between men and women; 3R - Relia: an analysis of the causes of gender distribution of resources and inequality in gender representation. Method $3 R$ is supplemented by $4 R$ - Realization: the formulation of new goals and measures and support the implementation of established strategic policy priorities ${ }^{19}$.

"Three Stages of Gender-Oriented Budgeting by Sheila Quinn". These steps correspond to the full cycle of processes required to apply the gender dimension as a category of analysis and control within the budget. Stage 1 is Budget Analysis. Stage 2 is Re-formulation of cost items in order to achieve the best results in the field of gender equality. Stage 3 is systematic work on the inclusion of gender elements in all budget processes ${ }^{20}$.

"7 tools of Diane Elson" is a methodology developed by the order of the Commonwealth Secretariat, first published in 1999 1. Evaluation of the provision of public services and budget priorities to beneficiaries by gender. 2. Analysis of the distribution of public expenditures. 3. Assessment of the degree of gender mainstreaming in implemented policies. 4. Gender-responsive budget usage report. 5. Analysis of the budget from the point of view of the use of time by sex. 6. Analysis of the concept of economic policy for the mediumterm period, taking into account the gender perspective. 7. Analysis of the distribution of government revenues by gender ${ }^{21}$.

Other well-known methods and approaches are the Belgian Approach to Legislation on Gender-oriented Budgeting, Women's Budget Report, etc.

The basis of Ukrainian practice is the study of the experience of different countries in the implementation of gender-oriented budgeting and practical work in Ukraine at the level of individual sectors. The experts of the NGO Bureau of Gender Strategies and Budgeting with the support of the United Nations Program of Women and the Representative Office of the Friedrich Ebert Foundation have developed methodology for gender budgeting in Ukraine with the aim of integrating the gender component into budgets of different levels: state, regional, local, as well as budgets of individual branches, institutions,

\footnotetext{
${ }^{19}$ Gender Mainsteaming Manual: A book of practical methods from the Swedish Gender Mainsteaming Support Committee. Swedish Government Official Reports. Stockholm, 2007. 69 p.

${ }^{20}$ Quinn S. Gender Budgeting: practical implementation : handbook. Directorate General of Human Rights and Legal Affairs. Strasbourg : Council of Europe Publishing, 2009. P. 16-20.

${ }^{21}$ Elson D. Budgeting for Women's Rights: Monitoring Government Budgets for Compliance with CEDAW. New York : UNIFEM, 2006. 180 p.
} 
organizations, etc. This technique includes five stages and the implementation of interrelated steps at each stage: 1) assessment of the initial situation and opportunities for work in a particular field; 2) gender budget analysis; 3 ) identification of gender-specific problems, goals and objectives of genderoriented budgeting; 4) the formation of gender-sensitive budget proposals and the calculation of the costs of their implementation; 5) assessment of the gender impact of planned budget measures ${ }^{22}$.

Let us take a closer look at the second stage of the methodology of "Conducting a Gender Budget Analysis", since gender analysis is at the heart of any gender budgeting initiative and is a key component of gender budgeting ${ }^{23}$. Through gender budgeting, specific types of activities, living conditions, needs, their access to resources and resource control, as well as access to the benefits of development and decision-making processes are explored for women and men.

A gender budget analysis of 26 programs funded at the expense of state and local budgets was carried out by working groups in ministries, oblast and Kyiv during 2016, which assessed the different impacts of existing policies, programs and legislation in the fields of education, health care, social security, youth policy, physical culture and sports for women and men from different social and demographic groups. A thorough study of the experience of different countries in implementing gender budgeting and practical work in Ukraine makes it possible to generalize gender budgeting approaches. The general scheme of gender budget analysis in local projects is as follows ${ }^{24}$ :

Step 1. Identifying gender issues in the field: an analysis of the situation. The analysis is aimed at obtaining a proper review of the target group of a specific program, identifying possible differences in the situation of this group, its practical and strategic needs and priorities, as well as finding out the existing manifestations of inequality between women and men (or subgroups of women and men) that need to be addressed with the help of state or regional policy.

Step 2. Baseline: collect information about the programs to be analyzed. In this step, the objectives of the program, the main directions of program activity, the budget allocated to the program, the share of financing coming from the state or local budgets, and which of the other sources are determined. Issues of the inclusion of specific goals for the promotion of gender equality are studied.

Step 3. Conducting a gender analysis of programs (activities, services). On the basis of the program review and collected information on the status of the target

\footnotetext{
22 Іваніна Т., Жукова О., Євченко С. Гендерно-орієнтоване бюджетування в Україні: теорія i практика : методичний посібник. Київ : Клименко, 2016. 92 с.

23 Літош А.Б., Забаштанський М.М., Зеленський С.М. Бюджетний аналіз у системі бюджетного планування. Вісник ЧДТУ. Серія «Економічні науки». 2011 . № 3 (52). С. 282-288.

${ }^{24}$ Гендерний бюджетний аналіз програм, які фінансуються 3 державного та місцевих бюджетів. Київ, 2016. 89 c.
} 
group and identified gender issues, a gender analysis of the program can be conducted, using different analytical tools for this.

Step 4. Conducting a gender analysis of budget expenditures. The analysis of consumers and beneficiaries carried out in the previous step at this stage is combined with the analysis of budgets. An analysis of the distribution of expenditures by sex is to determine the cost of programs (activities, services). This analysis is based on the calculation of the unit cost of services and the number of its consumers.

Step 5. Formulating goals and recommendations for enhancing gender equality. Recommendations for program measures may address such issues as introducing changes in measures to achieve the goals of gender equality and better addressing the priorities, needs and interests of women and men; ensuring equal access of women and men to various activities; improving the service delivery process; integrating a gender perspective into program activities, etc. Based on the developed recommendations, it is expedient to calculate the cost of expenditures for the purposes of gender equality ${ }^{25}$. Calculation of cost of expenses is a tool, with the help of which the estimated cost of expenditures for realization of one or another program or policy is made. This calculation is an important element of the world economic model and the model of the economy at the state level or its separate administrative unit, since well-calculated costs allow to mobilize financial resources for measures in various spheres.

Costing for gender equality is a monetary assessment of both financial and non-financial resources, which should be invested in the implementation of the state policy of gender equality ${ }^{26}$. Determining the necessary resources to implement gender policy priorities in life is the main goal of costing. This approach helps to determine the real value of gender-related activities and to promote its implementation and control. A feature of the method is that it can be used as a tool for gender analysis. Comparing the results of such an analysis with the actual expenditures of the state will increase the efficiency of using budget funds, taking into account the gender needs of the population. The costing of gender equality should be integrated into the gender analysis of current programs and budgets. It provides an opportunity to assess the needs for funding gender equality activities within the broader planning process of budgeting.

Finding ways to increase the efficiency of budget allocations is one of the objectives of gender budgeting initiatives, since they should be aimed at

\footnotetext{
25 Клацер Е., Іваніна Т. Гендерно-орієнтоване бюджетування: аналіз програм, які фінансуються 3 бюджету, з позиції гендерної рівності : посібник. 36 с.

${ }^{26}$ Costing of social and public policies for equality in Latin America and the Caribbean. Concept Note / Programme des Nations Unies pour le Développement. 2013. URL: https://www.slideshare.net/Gobernabilidad/ 1-presentacin-raquel-coello-marco-conceptual-eng.
} 
ensuring a balanced accounting of the interests and needs of women and men. This approach is somewhat related to budgeting methods that focus on socially meaningful results, which in recent years have been widely used by many countries. In each country, the methods of budgeting can be called differently. For example, result-based budgeting, productivity or performance management, program-target method, etc. However, all of them have a common goal, which is to achieve a concrete, long-term result that best meets the needs of society ${ }^{27}$.

For the first time, the issue of linking gender budgeting and outcome-based budgeting has been addressed by R. Sharp in his paper "Budgeting for Equity and Justice". She emphasized that both approaches have common features: they are result-oriented, contain clearly defined indicators for achieving these results and are aimed at improving the efficiency of budget process management ${ }^{28}$. The method for calculating the cost of expenses can be considered as a tool of the program-target budgeting method, as well as a component of the gender equality strategy implemented through the budget. In the context of budget reform in Ukraine, the application of such an approach is extremely timely. After all, the introduction of the program-target budgeting method makes this approach in demand, since it involves the transition to program budgeting at all levels. Reforms in the field of implementation of the program-target method provided a methodological basis for improving the budget process by focusing on gender and socially oriented results.

Implementation of the methodology of gender-oriented budgeting in the program-target method at all levels of government can significantly contribute to the achievement of the objectives of the program-target method: ensuring transparency of the budget process, budget funds and results of the implementation of the budget program; evaluation and analysis of achievement of goals and tasks, taking into account gender aspects; assisting the work of the funds managers in achieving the planned performance indicators; improving the quality of fiscal policy development, efficiency of distribution and use of budget funds; informing citizens about the course of planning and budget execution in order to involve them in the process of making managerial decisions ${ }^{29}$.

Both the program-target method and gender-oriented budgeting focus on results and on the wider policy planning cycle, implementation and evaluation ${ }^{30}$.

\footnotetext{
27 Сучасні інструменти фінансового планування : навчальний посібник / за заг. ред. І.Ф. Щербини. Київ : Нора-Друк, 2011. С. 6.

${ }^{28}$ Sharp R. Budgeting for equity: gender budget initiatives within a framework of performance oriented budgeting. New York : United Nations Development Fund for Women (UNIFEM), 2003. 86 p.

${ }^{29}$ Klatzer E. The integration of Gender Budgeting in Performance-Based Budgeting. Bilbao: Watch Group. Gender and Public Finance, 2008. P. 7.

${ }^{30}$ Босніч М., Шаповал М. Інноваційний підхід до програмного бюджетування: ПЦМ з гендерної точки зору - результати і переваги. 2017. 20 с.
} 
The strategy of reforming the public finance management system for 20172020 states: "The application of the program-target method in the budget process in Ukraine is still carried out without the fulfillment of the mandatory conditions, namely the availability of a long-term strategy for Ukraine's development and the introduction of strategic and medium term budget planning. As a result, the program-target method is used only formally. The Ministry of Finance is taking measures to increase the effectiveness of the program-target method". "The program-target method should ensure the optimal use of limited budget resources to achieve maximum efficiency and quality of government services <...> Further improvement of the system of effective indicators of budget programs should be aimed at strengthening their focus on coverage and quality of public services and their satisfaction recipients" ${ }^{\prime 31}$.

The gender budget analysis and the program-target method are aimed at focusing on the outcomes and results of the budget policy (while the traditional methods of budgeting are the determinants of expenditures). Expanded accountability, enhanced democracy, transparency, and better governance are elements of both approaches. In addition, the program-target method involves the existence of a system for evaluating and monitoring the implementation of budget programs ${ }^{32}$, which is a prerequisite for conducting a gender analysis of such programs. Thus, the scope of application of the program-target method can be expanded, and its effectiveness is improved through the integration of gender aspects.

Taking into account the gender aspect, formation of the budget imposes certain requirements for the compilation and submission of budgetary requests and passports of budget programs by sector ministries and authorities, which provides for a high level of interdependence and interaction of state bodies. Budget programs in the areas of public administration, health care, education, culture, social security, physical culture and sports, youth programs, etc. contain objectives and targets for their implementation: cost, product, efficiency, quality ${ }^{33}$. It is expedient to include "gender indicators" or "indicators of gender equality achievement" in such indicators which would be used to assess gender mainstreaming in the budget process.

The above-mentioned proposals require amendments to the Budget Code of Ukraine, which will include the application of a gender perspective in the

\footnotetext{
31 Про схвалення Стратегії реформування системи управління державними фінансами на 20172020 роки: Розпорядження Кабінету Міністрів України від 08.02.2017 № 142-р. Офіційинй вісник Украӥни. 2017. № 23. Ст. 659.

${ }_{32}$ Корнієнко Н.М. Оцінка і моніторинг ефективності бюджетних програм. Економічний часопис - XXI. 2013. № 5-6 (2). С. 31.

33 Корнієнко Н.М., Остріщенко Ю.В. Гендерний складник бюджетної політики держави. URL: http://visnik.knteu.kiev.ua/files/2016/01/8.pdf.
} 
program-target method at the stages of the budget process, as well as the normative legal acts that are applied in the budget process and regulate the formation of budget requests and passports of budget programs: Order of the Ministry of Finance of Ukraine of December 29, 2002 "On Passports of Budget Programs"; Order of the Ministry of Finance of Ukraine dated 06.06.2012 "On Approval of Instructions for Preparing Budget Queries"; Order of the Ministry of Finance of Ukraine dated December 10, 2010 "On Performance Indicators of the Budget Program", as well as normative legal acts regulating the standard lists of budget programs in the branches of the budget sphere at the local level.

\section{CONCLUSIONS}

Thus, summing up the coverage of the gender budgeting section, we can draw the following conclusions.

1. In the context of retrospective gender budgeting is a relatively new phenomenon that arose at the end of the $20^{\text {th }}$ century. In Ukraine, gender budgeting is under development. It is necessary to distinguish between the terms "gender budget" and "gender budgeting". Gender budgeting is one of the tools for achieving gender equality, the mechanism of which covers the political, economic and social spheres of ensuring equality between women and men. Gender-oriented budgeting is an instrument that enables the state policy to guarantee equal rights and opportunities for women and men at the expense of budgetary funds. The terms gender budget, gender-oriented budget, gendersensitive budget, gender responsive budget are synonymous. The gender budget is a balanced consideration of the needs and interests of women and men through the introduction of methods aimed at integrating the gender component into the budget process at all levels of the budget system.

2 . In the beginning of 2000 , more than 40 countries applied gender budgeting to a greater or lesser extent. In many cases, the initiative was constrained by the lack of statistical data or the lack of cooperation from the government at different levels. However, many countries have begun implementing gender budgets as pilot projects, and in some countries such projects have made significant progress. Today, more than 90 countries are implementing various gender budget initiatives that cover civil society, governments and international organizations. In Ukraine, for more than 10 years, various gender budget initiatives have been implemented with the support of international programs and projects. This provided some experience in gender budgeting and integration of gender approaches into budgets of different levels.

3. Implementation of the method of gender-oriented budgeting into the program-target method at all levels of government can contribute to the achievement of the objectives of the program-target method: ensuring 
transparency of the budget process, budget funds and results of the implementation of the budget program; evaluation and analysis of achievement of goals and tasks, taking into account gender aspects; assisting the work of the funds managers in achieving the planned performance indicators; improving the quality of fiscal policy development, efficiency of distribution and use of budget funds; informing citizens about the course of planning and execution of the budget in order to involve them in the process of making administrative decisions. The program-target method and gender-oriented budgeting focus on the results and the planning, implementation and evaluation cycle of the policy. Gender budget analysis and program-target method are aimed at focusing on the outcomes and results of budget policy. Taking into account the gender aspect, formation of the budget imposes certain requirements for the compilation and submission of budgetary requests and passports of budget programs by sector ministries and authorities, which provides for a high level of interdependence and interaction of state bodies. Budget programs should include "gender indicators" or "indicators of gender equality achievement" that would be used to assess gender mainstreaming in the budget process. These proposals need to be amended in the Budget Code of Ukraine, which will involve the use of a gender perspective in the program-target method at the stages of the budget process, the regulatory acts that are applied in the budget process and regulate the formation of budget requests and passports of budget programs, as well as to the normative legal acts regulating the standard lists of budgetary programs in the branches of the budget sphere at the local level.

\section{SUMMARY}

The paper discusses the issues of gender budgeting in the mechanism of ensuring the principle of gender equality. It is emphasized that in the context of retrospective gender budgeting is a relatively new phenomenon that arose at the end of the $20^{\text {th }}$ century. In Ukraine, gender budgeting is under development. The article specifies that gender budget, gender-oriented budget, gender-sensitive budget, gender responsive budget are synonymous. The definitions of genderoriented budgeting and gender-oriented budget are formulated. The stages of gender budget analysis within the framework of local projects are proposed. It is highlighted that the program-target method and gender-oriented budget are focused on the results and on the planning, implementing and evaluating of the policy. It is stressed that budget programs should include "gender indicators" or "indicators of gender equality achievement" that would be used to assess gender mainstreaming in the budget process. 


\section{REFERENCES}

1. Пекінська декларація (укр./poc.), прийнята на четвертій Всесвітній конференції зі становища жінок 15.09 .1995 p. Бібліотечка голови профспілкового комітету. 2005. № 5. URL: http://zakon3.rada.gov.ua/laws/ show/en/995_507.

2. Грицай I.O. Теоретико-правові засади гендерно-оріснтованого бюджетування: зарубіжний досвід та вітчизняна практика. Науковий вісник публічного та приватного права. 2017. № 6. С. 3 -8.

3. Романюк О. Потенціал України та його реалізація. Аналітичний звіт Міжнародного иентру перспективних досліджень. Київ, 2009. 69 с.

4. Гаращенко С.В. Гендерне бюджетування як складник політичних механізмів сприяння забезпеченню рівності жінок та чоловіків. Наукові записки. Т. 95. С. 47-51. URL:

http://ekmair.ukma.edu.ua/bitstream/handle/123456789/3999/Harashchenko_He nderne.pdf.

5. Гендерний бюджетний аналіз програм, які фінансуються 3 державного та місцевих бюджетів. Київ, 2016. 89 с.

6. Остріщенко Ю.В., Корнієнко Н.М. Гендерне бюджетування на місцевому рівні як інструмент підвищення ефективності використання бюджетних коштів. Механізм регулювання економіки. 2015. С. 19-27.

7. Іваніна Т., Жукова О., Євченко С. Гендерно-орієнтоване бюджетування в Україні: теорія і практика: методичний посібник. Київ : Клименко, 2016. 92 с.

8. Global Monitoring Report 2007: Confronting the Challenges of Gender Equality and Fragile States. World Bank and International Monetary Fund. URL: https://www.imf.org/external/pubs/ft/GMR/2007/eng/gmr.pdf.

9. Budlender D., Hewitt G. Gender Budgets Make More Cents Country Studies and Good Practice. Commonwealth Secretariat. Marlborough House, Pall Mall, London. 2002. 194 p.

10. Геппл М., Фестл Э. Гендерное бюджетирование в Австрии. Первый опыт. Польша. 2015. 11 c. URL: http://www.pempal.org/sites/pempal/ files/event/attachments/d1-pm-s2.b-monica-geppl-austria_rus.pdf.

11. Матеріали до семінарів із впровадження гендерних підходів у політику. Програма підтримки партнерства жінок та чоловіків у політиці «Ольга». Київ: б. в., 2002. 49 с.

12. Country Specific Information. European institute for gender equality. URL: http://eige.europa.eu/gender-mainstreaming/countries.

13. Strengthening economic and financial governance through gender responsive budgeting. Conference report. Brussels. 2001. URL: 
https://www.internationalbudget.org/wp-content/uploads/gender_report_conf_ oct01.pdf.

14. Малиняк Б., Іваніна Т., Гаращенко С. Гендерне бюджетування в Україні. Київ : б. в., 2010. 34 с.

15. ООН Жінки. ЮНЕЙДС. URL: https://unaids.org.ua/ua/aboutunaids/diyalnist-v-ukrajini/oon-zhinky.

16. Budlender D., Elson D. Gender Budgets Make Cents: Understanding Gender Responsive Budgets. Gender Affairs Department. 2002, 180 p. URL: https://www.internationalbudget.org/wp-content/uploads/Gender-BudgetsMake-Cents-Understanding-Gender-Responsive-Budgets.pdf.

17. Written comments of the European Roma Rights Centre and the International Charitable Organization Roma Women Fund "Chiricli" Concerning the Republic of Ukraine for consideration by the Committee on the Elimination of All Forms of Discrimination against Women at its 45th session. URL: http://chirikli.com.ua/index.php/ua/component/k2/item/82written-comments-by-the-european-roma-rights-centre-and-the-internationalcharitable-organization-roma-women-fund-chiricli.

18. Austrian Experience Performance Budgeting. Friederike Schwarzendorfer. Austrian Federal Ministry of Finance. 57 p. URL: https://slideplayer.com/slide/12030238/

19. Frey R., Köhnen M. Guidance Gender Budgeting in Public Administration. Vienna, 2012.43 p.

20. Gender Mainsteaming Manual : A book of practical methods from the Swedish Gender Mainsteaming Support Committee. Swedish Government Official Reports. Stockholm, 2007. 69 p.

21. Quinn S. Gender Budgeting: practical implementation : handbook. Directorate General of Human Rights and Legal Affairs. Strasbourg : Council of Europe Publishing, 2009. 80 p.

22. Elson D. Budgeting for Women's Rights: Monitoring Government Budgets for Compliance with CEDAW. New York : UNIFEM, 2006. 180 p.

23. Літош А.Б., Забаштанський М.М., Зеленський С.М. Бюджетний аналіз у системі бюджетного планування. Вісник ЧДТУ. Серія «Економічні науки». 2011. № 3 (52). С. 282-288.

24. Клацер Е., Іваніна Т. Гендерно-орієнтоване бюджетування: аналіз програм, які фінансуються з бюджету, з позиції гендерної рівності : посібник. $36 \mathrm{c.}$

25. Costing of social and public policies for equality in Latin America and the Caribbean. Concept Note / Programme des Nations Unies pour le Développement. 2013. URL: https://www.slideshare.net/Gobernabilidad/1presentacin-raquel-coello-marco-conceptual-eng. 
26. Сучасні інструменти фінансового планування : навчальний посібник / за заг. ред. І.Ф. Щербини. Київ : Нора-Друк, 2011. 128 с.

27. Sharp R. Budgeting for equity: gender budget initiatives within a framework of performance oriented budgeting. New York : United Nations Development Fund for Women (UNIFEM), 2003. 86 p.

28. Klatzer E. The integration of Gender Budgeting in Performance-Based Budgeting. Bilbao: Watch Group. Gender and Public Finance, 2008. 17 p.

29. Босніч М., Шаповал М. Інноваційний підхід до програмного бюджетування: ПЦМ з гендерної точки зору - результати і переваги. 2017. $20 \mathrm{c}$.

30. Про схвалення Стратегії реформування системи управління державними фінансами на 2017-2020 роки : Розпорядження Кабінету Міністрів України від 08.02.2017 № 142-р. Офіиійний вісник України. 2017. № 23. Ст. 659.

31. Корнієнко Н.М. Оцінка i моніторинг ефективності бюджетних програм. Економічний часопис - XXI. 2013. № 5-6 (2). С. 31-33.

Information about authors:
Nalyvaiko L. R.,
Doctor of Law, Professor,
Honored Lawyer of Ukraine,
University of Internal Affairs
Gagarina, 26, Dnipro, Ukraine

Vice-Rector of the Dnipropetrovsk State University of Internal Affairs
Ave. Gagarina, 26, Dnipro, Ukraine

Hrytsai I. O.,

Doctor of Law, Associate Professor, Head of the Department of Social and Humanitarian Disciplines Dnipropetrovsk State University of Internal Affairs Ave. Gagarina, 26, Dnipro, Ukraine 